founder of the first permanent English colony in America) the book carries the story of American development down through the work of John Hancock, John Jacob Astor, Jay Cooke \& Company, the Massachusetts-First National Bank of Boston, the Dennison Manufacturing Company, the Chicago, Milwaukee, St. Paul \& Pacific Railway Company, J. Pierpont Morgan, Elbert Gary and the United States Steel Corporation, and other men and enterprises. For background or comparison a few European studies are also included, notably John Law (financier and speculator), Boulton \& Watt, and Josiah Wedgwood \& Sons, Ltd. The book contains studies of over thirty individuals or firms from the various periods in business history.

While emphasis is on the individual unit, there is recognition of the fact that business men must operate within the setting in which they live. Systems of thought, forms of government, and general business conditions are among the important larger influences which bear upon the work of the individual business man. One case, "Early Economic Systems, Especially Mercantilism," is concerned with the thought and institutions within which business operated for a long time in the past, while "Recent Economic Systems" deals with developments in our time. Four cases on business trends give a brief survey of important factors influencing American business in the past and tentatively set forth a long-time pattern of business behavior that is significant.

\title{
The Collection of Business Records at the University of Illinois
}

The organized collection of business records at the University of Illinois was begun in November, 1936, when Dean C. M. Thompson and a colleague approached several business houses in the southern part of the State. In the short space of three years over thirty-five hundred firms have been contacted either personally or by mail, and hundreds of thousands of items have been collected. 
A wide range of material has been gathered, not only from Illinois firms, but also from organizations which are national in scope. The collection includes items ranging from advertisements which appeared yesterday to the books of Illinois firms of a hundred years ago. Books of original entry have been obtained from elevators, clothing stores, general stores, breweries, wholesale groceries, dairies, jewelry stores, hardware stores, banks, traction companies, and department stores. Also, the private correspondence of lawyers, labor leaders, and others has been collected.

The objects of this collection are several. First, we aim to preserve a part of our civilization and culture which in the past has been very inadequately preserved. Our present-day advertising reflects our culture just as much as the literature, architecture, and sculpture of the Greeks and Romans reflect the culture of their day. In fact, it is perhaps not too much to say that the business literature and records of today reflect our daily life more completely than a few ruined buildings could ever do. Second, we wish to have immediately accessible specific information relating to the policies and practices of present-day firms which can be used as illustrative material in the classroom. Third, it is our desire to furnish documentary evidence for present and future business historians. Even the most inexperienced student of business history appreciates the difficulty of obtaining sufficient evidence from which to write a connected story or draw satisfactory conclusions. Fourth, we plan to have our collections in such form as to be readily available to those persons who are writing theses in various fields. In the past students in banking, finance, marketing, and other fields have approached us with splendid subjects for research, but these subjects could not be attempted because of the difficulty of assembling even the known available information. In the future our collection will increasingly overcome this difficulty.

So far our collection has been available only to teachers and advanced students, since it is housed in temporary quarters in a number of places. The cataloguing also is not complete.

Fred M. Jones,

University of Illinois. 